\title{
Life Estimation of Transfer Lines for Tank Farm Closure Performance Assessment
}

\author{
K. H. Subramanian \\ Savannah River National Laboratory \\ Materials Science and Technology Directorate
}

Publication Date: October 2007

\section{Washington Savannah River Company Savannah River Site Aiken SC 29808}

This document was prepared in connection with work done under Contract No. DE-AC09-96SR18500 with the U. S. Department of Energy 


\section{DISCLAIMER}

This report was prepared as an account of work sponsored by an agency of the United States Government. Neither the United States Government nor any agency thereof, nor any of their employees, makes any warranty, express or implied, or assumes any legal liability or responsibility for the accuracy, completeness, or usefulness of any information, apparatus, product, or process disclosed, or represents that its use would not infringe privately owned rights. Reference herein to any specific commercial product, process, or service by trade name, trademark, manufacturer, or otherwise does not necessarily constitute or imply its endorsement, recommendation, or favoring by the United States Government or any agency thereof. The views and opinions of authors expressed herein do not necessarily state or reflect those of the United States Government or any agency thereof. 
DOCUMENT:

TITLE:

APPROVALS
WSRC-STI-2007-00460

Life Estimation of Transfer Lines for Tank Farm Closure Performance Assessment

SIGNATURES ON FILE 


\section{Table of Contents}

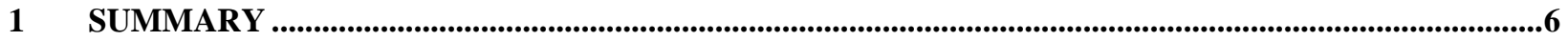

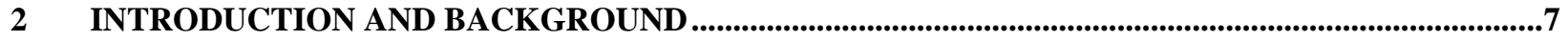

2.1 TYPE I TRANSFER LINES CONSTRUCTION AND CONFIGURATION ..............................................................

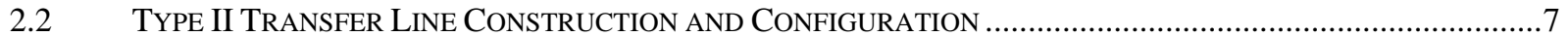

2.3 TYPE III TRANSFER LINE CONSTRUCTION AND CONFIGURATION ...........................................................

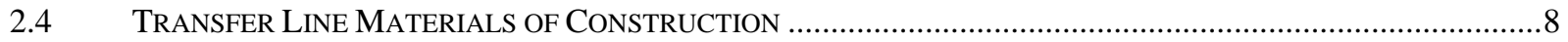

3 TRANSFER LINE LIFE ESTIMATION TECHNICAL APPROACH.....................................................

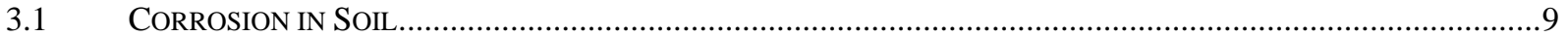

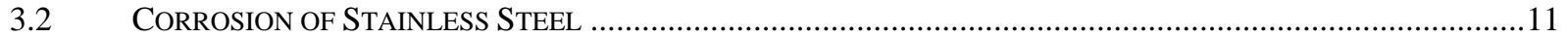

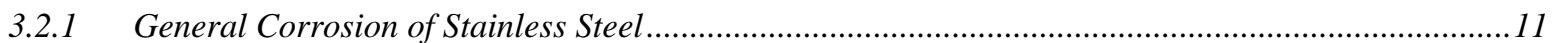

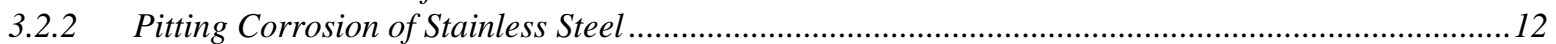

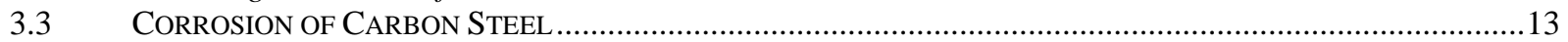

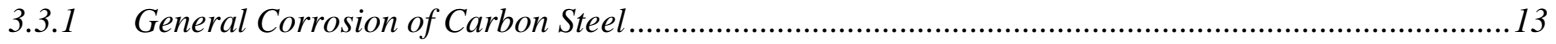

3.3.2 Pitting Corrosion in Carbon Steels....................................................................................................14

$4 \quad$ TRANSFER LINE LIFE ESTIMATION RESULTS ...................................................................................14

4.1 LIFE ESTIMATION OF STAINLESS STEEL TRANSFER LINES..........................................................................15

4.2 LIFE ESTIMATION OF CARBON STEEL TRANSFER LINES ......................................................................

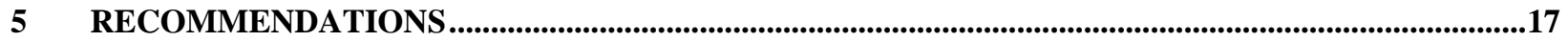

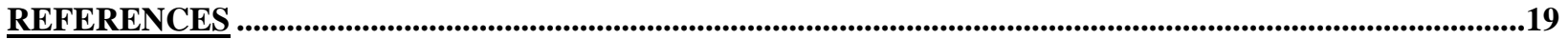




\section{List of Tables}

TABLE 1: Nominal Dimensions of CoRE PIPING FOR TYPE II AND IIA TRANSFER LINES.............................................

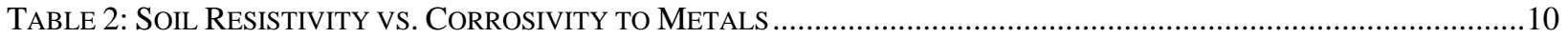

TABLE 3: SOIL RESISTIVITY DATA FOR AREA SURROUNDING THE F-AREA TYPE IV TANKS. .......................................10

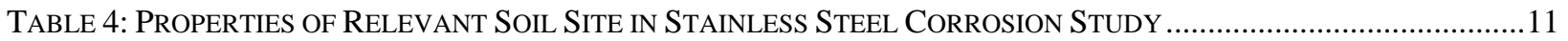

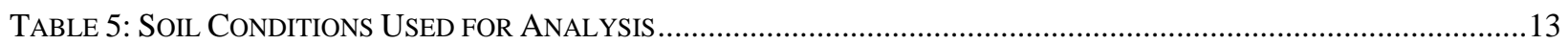

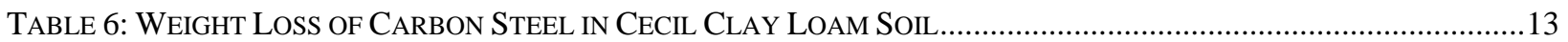

\section{List of Figures}

FiguRE 1: RECOMMENDED LifE ESTIMATION FOR STAINLESS STEEL TRANSFER LiNES FOR CONTAMINANT MODELING.

(n)

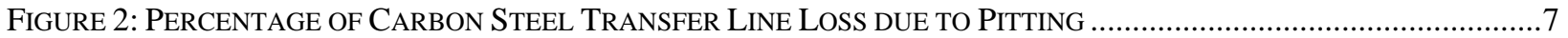

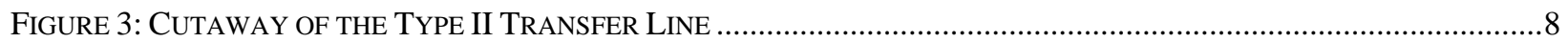

FIgURE 4: CORROSION RATE VS. TIME FOR SENSITIZED TYPE 304-SS EXPOSED TO SITE 'B' ...................................12

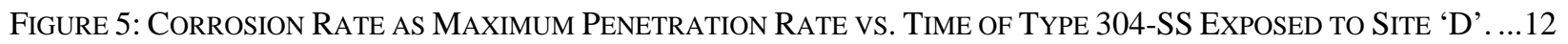

Figure 6: CORROSION RATE AND MAXIMUM PENETRATION RATE AS A FUnCTION OF TIME. ...................................14

Figure 7: GENERAL CoRrosion OF SCHEdUlE 40 STAINLESS STEEL TRANSFER LiNES EXPOSED TO SOIL .................15

Figure 8: Percentage of Area Breached of StAinless SteEl Transfer Line due to PitTing IN SoIL ............16

FIGURE 9: CORROSION OF CARBON STEEL TRANSFER LINE EXPOSED TO SOIL ...................................................17

FIGURE 10: RECOMMENDED LIFE ESTIMATION FOR STAINLESS STEEL TRANSFER LiNES FOR CONTAMINANT

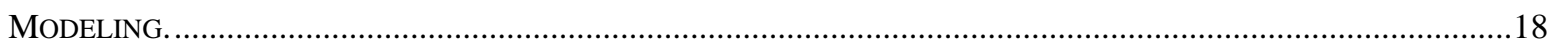

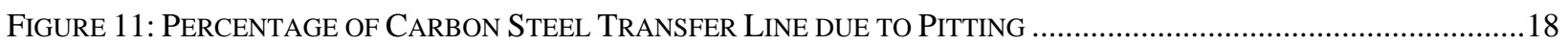




\section{SUMMARY}

A performance assessment is being performed in support of closure of the F-Tank Farm. The performance assessment includes the life estimation of the transfer lines that are used to transport waste between tanks both within a facility ('intra-area' transfer) and to other facilities ('inter-area' transfers). The transfer line materials of construction will initially provide a barrier to contaminant escape. However, the materials will degrade over time, most likely due to corrosion, and will no longer provide a barrier to contaminant escape. The life estimation considered the corrosion of the core pipe under exposure to soil, estimated the thickness loss due to general corrosion, and the percentage of wall area breached due to localized corrosion mechanisms. There are three types of transfer lines that are to be addressed within the performance assessment: Type I, Type II/IIA and Type III. The life of the transfer lines were estimated as exposed to soil. Localized and general corrosion of the transfer lines exposed to soil was estimated to provide input to the fate and transport modeling of the performance assessment.

Pitting corrosion was found to be the controlling mechanism for the degradation of the transfer lines and their consequent ability to maintain confinement of contaminants. It is assumed that $75 \%$ of the transfer line is needed intact to provide this confinement function, i.e. once $25 \%$ of the line wall is breached, the lines are considered incapable of confining contaminants. It is recommended that the percentage breached curves be utilized for each transfer line as shown in Figure 1 for the various stainless steel transfer lines.

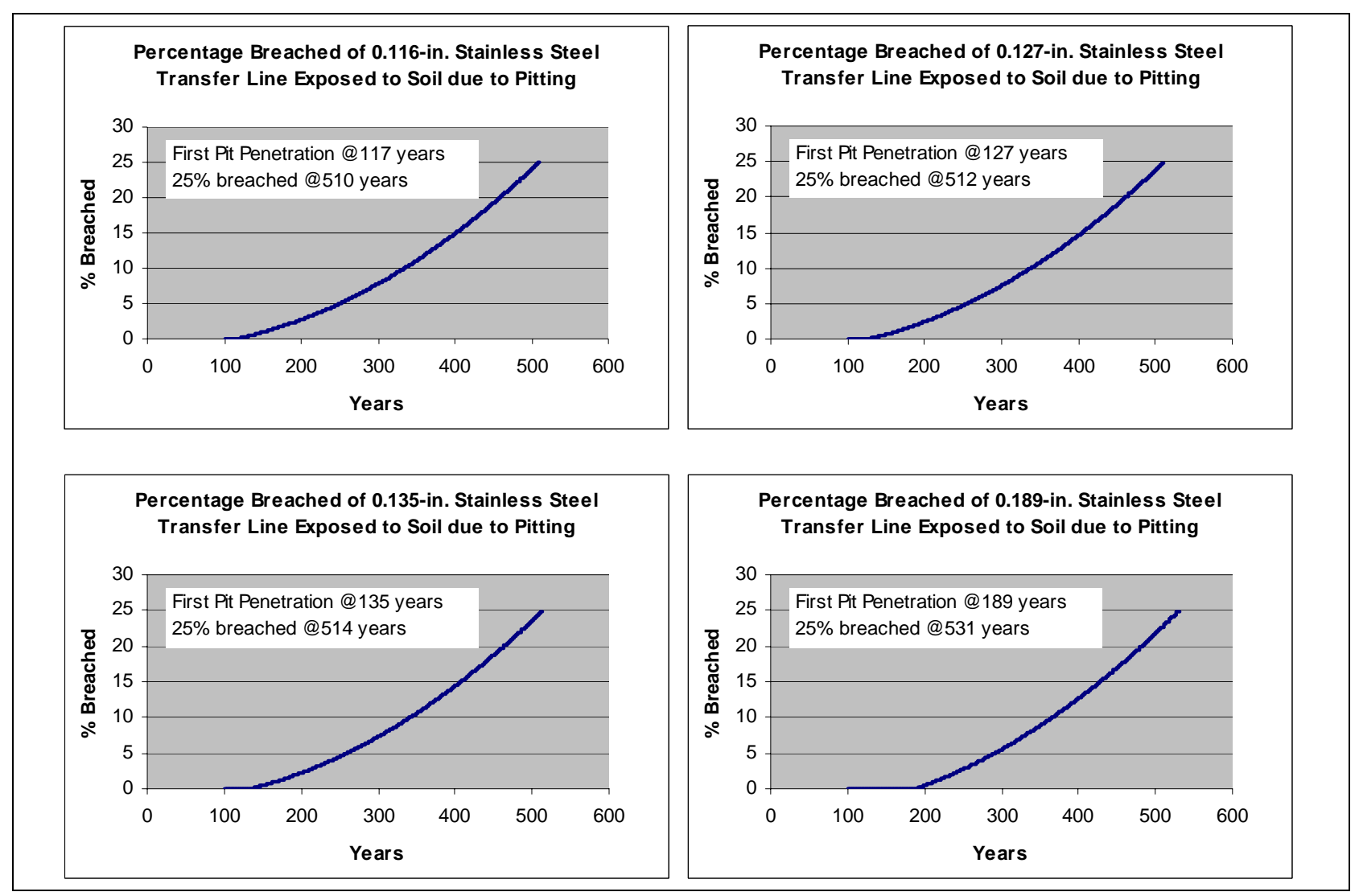

Figure 1: Recommended Life Estimation for Stainless Steel Transfer Lines for Contaminant Modeling.

A similar curve was developed for the carbon steel transfer lines, as shown in Figure 2. The first pit is estimated to penetrate at 45 years, and $25 \%$ of the line wall is breached at an estimated 98 years. 


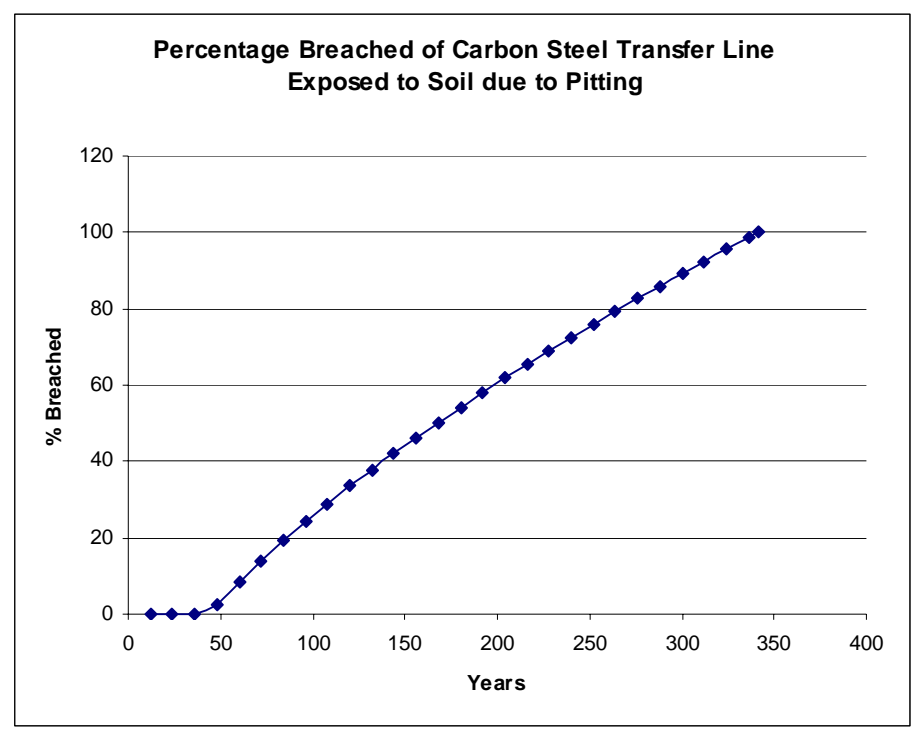

Figure 2: Percentage of Carbon Steel Transfer Line Loss due to Pitting

\section{INTRODUCTION AND BACKGROUND}

High level radioactive waste (HLW) is stored in underground storage tanks at the Savannah River Site. The SRS is proceeding with closure of the 22 tanks located in F-Area. Closure consists of removing the bulk of the waste and filling the tank with tailored grout formulations and severing/sealing external penetrations. A performance assessment is being performed in support of closure of the F-Tank Farm. The performance assessment includes the life estimation of the transfer lines that are used to transport waste between tanks both within a facility ('intra-area' transfer) and to other facilities ('inter-area' transfers). There are three types of transfer lines that are to be addressed within the performance assessment: Type I, Type II/IIA and Type III.

The transfer line materials of construction will initially provide a barrier to contaminant escape. However, the materials will degrade over time, most likely due to corrosion, and will no longer provide a barrier to containment escape. The life estimation considered the corrosion of the core pipe under exposure to soil, estimated the thickness loss due to general corrosion, and the percentage of wall area breached due to localized corrosion mechanisms.

\subsection{Type I Transfer Lines Construction and Configuration}

The Type I transfer lines are the oldest transfer lines and are nominally a 3-in. diameter, schedule-40 (0.216-in. thickness) pipe made of a Type 304 stainless steel. The secondary containment is provided by a waterproof concrete encasement.

\subsection{Type II Transfer Line Construction and Configuration}

The Type II transfer line make up the majority of all transfer lines and are constructed of a stainless steel pipe inside a carbon steel containment pipe which drains to a detection box. All pipe joints (transfer lines and containment pipes) are welded and leak-tested.

Figure 3 shows a cut-away drawing of the Type II transfer line consisting of a stainless steel pipe inside a carbon steel jacket which drains to a leak detection box (LDB). The pipe is installed with a gravity slope. A few Type IIA transfer lines consist of a carbon steel core pipe within a carbon steel jacket. All pipe joints (transfer lines and containment pipes) are welded. Any portion of the carbon steel containment piping in direct contact with the soil is protected against corrosion by a polyethylene film wrap or a bituminous coating (a non metallic type of asphalt). The majority of Type II transfer lines are coated with either a Gilsotherm ${ }^{\mathrm{tm}}$ or Gilsolate $^{\mathrm{tm}}$ (a hydrophobic inorganic insulating powder) envelope. 


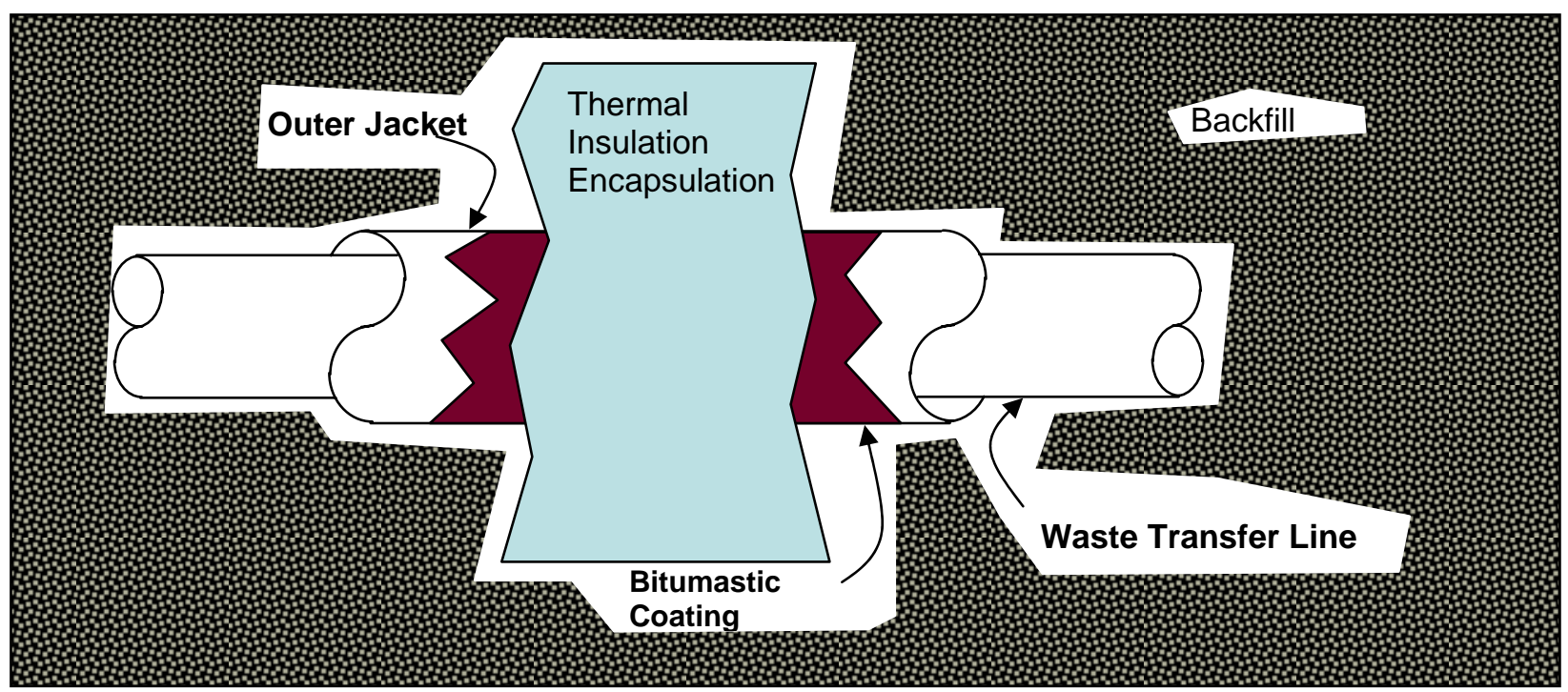

Figure 3: Cutaway of the Type II Transfer Line

Table 1: Nominal Dimensions of Core Piping for Type II and IIA Transfer Lines

\begin{tabular}{|c|c|c|}
\hline Description & $\begin{array}{l}\text { Nominal } \\
\text { Thickness (in.) }\end{array}$ & $\begin{array}{c}\text { Minimum } \\
\text { Thickness* (in.) }\end{array}$ \\
\hline 1" diameter Sch. 40 Stainless Steel Core & 0.133 & 0.116 \\
\hline 1.5" diameter Sch. 40 Stainless Steel Core & 0.145 & 0.127 \\
\hline 2" diameter Sch. 40 Stainless Steel Core & 0.154 & 0.135 \\
\hline $\begin{array}{l}\text { 3" diameter Sch. } 40 \text { Stainless Steel Core } \\
\text { (3 lines were measured) }\end{array}$ & 0.216 & 0.189 \\
\hline $\begin{array}{l}\text { 3" diameter Sch. } 40 \text { Carbon Steel Core } \\
\text { (5 lines were measured) }\end{array}$ & 0.216 & 0.189 \\
\hline
\end{tabular}

* - Minimum thickness is $0.875 \mathrm{x}$ nominal thickness [1]

\subsection{Type III Transfer Line Construction and Configuration}

Type III transfer lines were constructed in the late 1950's and are utilized to transfer low level waste. The line consists of a 3-in. schedule 40 ( 0.216 nominal wall thickness) stainless steel core pipe surrounded by a cementasbestos jacket also referred to as transite.

\subsection{Transfer Line Materials of Construction}

The transfer line core piping is primarily constructed of Type 304 with some (Type IIA) constructed with low carbon steel. Type 304 stainless steel has a nominal composition of $18 \%$ chromium and $8 \%$ nickel that makes is generally corrosion resistant to a wide variety of environments. However, Type 304 can undergo "sensitization" experiencing chromium depletion along the grain boundaries, making it susceptible to corrosion and particularly chloride attack. Type 304L grades with low carbon content are available that minimize the potential for susceptibility. The Type IIA core transfer pipe is made of low carbon steel assumed to be similar to the carbon steel jackets that are used as secondary containment for the transfer line jackets of the Type II transfer lines.

\section{TRANSFER LINE LIFE ESTIMATION TECHNICAL APPROACH}

The life of the transfer line steels and performance as a barrier to radionuclide escape is dependent upon the active corrosion mechanisms under closure conditions. Many of the transfer lines are encased in concrete, which, in general, prevents corrosion of the steel by: (1) forming a passive oxide on the steel surface, (2) maintaining a high 
$\mathrm{pH}$ environment, and (3) providing a matrix resistant to diffusion of aggressive species. The passivity of the steel at the interface can be controlled by the dynamic characteristics of the "pore water" (interstitial solution ) within the concrete.[2] The passivity is maintained at the high $\mathrm{pH}$ environments in the region of water stability. However, as pore water characteristics change with the introduction of chlorides or carbon dioxide, the passive film on the steel may break down. The life of the transfer lines was estimated as exposed to soil, however, which is considered a more aggressive condition, and does not allow credit for the concrete structure. Localized and general corrosion of the transfer lines exposed to soil was estimated to provide input to the fate and transport modeling of the performance assessment. The analysis has been reproduced from reference 3 and extended to the transfer line life estimation. [3]

\subsection{Corrosion in Soil}

Corrosion is a chemical or electrochemical reaction between a material, usually a metal, and its environment that produces a deterioration of the material and/or its properties. Corrosion occurs through the loss of metal ions at anodic areas on a structure. The base metal is oxidized at the anode to form positively charged metal ions which combine with the negatively charged ions in the soil to form metal oxide corrosion products. The surplus of electrons from the anode combine with positively charged hydrogen ions from the soil environment to form hydrogen and a passivating film on the metal surface.

Soil characteristics that influence the type and extent of corrosion of steel include [4]:

- $\quad$ aeration and permeability characteristics of the soil;

- soil acidity;

- dissolved salt content and resistivity of the soil.

Aeration and permeability are the primary attributes of soil that impact corrosion due to the fact that they control the access of oxygen and water to the steel surface. Aeration and permeability characteristics of soil depend on physical characteristics such as particle size and distribution, specific gravity, topography, water table depth, and amount of rainfall.

Corrosion typically occurs to a lesser degree in porous soils with good drainage and ample oxygen supply (e.g., sandy soils). Metal exposed to clayey soils, which tend to have high water retention, poor aeration, and poor drainage exhibit significantly higher corrosion rates. Corrosion by differential aeration may also occur, , for example, a structure passes through two soils that differ in oxygen permeability. Corrosion due to differential aerations occurs when a galvanic current flows from the poorly aerated surface (i.e., anode) to the aerated surface (i.e., cathode). Lower oxygen concentrations typically occur at the bottom of a buried structure where the soil is more compact and farther from the source of oxygen in the atmosphere. Thus, the bottom of the buried structure is potentially more susceptible to corrosion. Corrosion may also occur due to oxygen concentration cells, typically found in backfilled soils due to the presence of rocks and other foreign materials.[5]

The acidity or alkalinity of the soil also factors into the corrosion response of a material in soil. Steel in an acidic environment $(\mathrm{pH}<4)$ tends to corrode rapidly in a general or uniform mode. Pitting corrosion tends to predominate in a neutral to slightly alkaline environment $(4<\mathrm{pH}<10)$, becoming less aggressive as the $\mathrm{pH}$ increases. In alkaline environments $(\mathrm{pH}>10)$, steel corrosion is minimal due to the stability of the passive oxide film on the metal surface.

The most corrosive soils are those that contain large concentrations of soluble salts (e.g., chloride) which lead to low electrical resistivity, the property most commonly used to approximate the aggressiveness of a soil. Resistivity measurements are readily attainable and yield measurements that trend well with corrosivity levels of the soil. Table 2 lists the general relationship that exists between soil resistivity and the corrosion of steel in soils [6]. Backfilled soils may have a lower resistivity due to the accumulation of salts in these areas. Caution should be utilized in applying these classifications as aeration and soil acidity could also factor into the corrosive soil conditions. Additionally, resistivity measurements may vary over time due to changes in the moisture content of the soil. 
Table 2: Soil Resistivity vs. Corrosivity to Metals

\begin{tabular}{|c|l|}
\hline Resistivity, ohm -centimeter & \multicolumn{1}{|c|}{ Corrosivity } \\
\hline Below 500 & Extremely Corrosive \\
\hline $500-1,000$ & Corrosive \\
\hline $1,000-2,000$ & Moderately Corrosive \\
\hline $2,000-10,000$ & Mildly corrosive \\
\hline Above 10,000 & Progressively less corrosive \\
\hline
\end{tabular}

SRS soils are generally classified as clayey sand or sandy clay that contains 20 to $40 \%$ clay [7]. The soil characteristics were reviewed and are summarized as follows:

- Moisture content from soil samples averaged from approximately $9 \%$ to approximately $38 \%$. [7,8]

- Soil texture over a large part of the site is described as loamy and composed of particles that are clay, silt, and sand. The texture contributes to the well drained to excessively drained soil characteristics in most areas [9].

- $\quad$ pH ranging from acidic to slightly alkaline ( $\mathrm{pH}$ of 3.6 to a high of 8 ) have been observed, but typical values are almost neutral $\mathrm{pH}[7,9]$.

- $\quad$ Specific conductance measurements indicate very low soluble salt levels in the soils at SRS, which is probably the result of continued leaching by percolating rain water. (Chloride and sulfate leachate levels were tested as relatively low.)

- Soil resistivity measurements taken at depths of 5 feet to 20 feet ranged from 2300 ohm-cm to 149,000 ohm-cm.

Soil characteristics at the SRS, which include well drained and excessively drained soils, low total dissolved solids, and neutral $\mathrm{pH}$, indicate that the potential for underground corrosion is relatively low. However, underground corrosion of piping at the SRS is well documented.[10] Soil surveys in the F and H area tank farms have indicated a generally high resistivity with pockets of lower resistance.[9, 11] The possibility of corrosion is low in high resistivity soils, but the soil may be locally corrosive at the lower resistivity. Numerous lateral and vertical changes between sands and clays over short distances, which are typical of the coastal plain environment, were observed in the Defense Waste Processing Facility area.[12] Large variations in soil resistivity provide for a possibility of galvanic corrosion. Galvanic corrosion usually appears when the pipe traverses soils of different composition, and as a result one section of the pipe becomes anodic with respect to another.

Table 3 shows soil resistivity data specific to the Type IV tanks in F-area at two locations as a function of depth. The resistivities are relatively high and consistent suggesting a low potential for corrosion. The average $\mathrm{pH}$ of the well water in the $\mathrm{F}$ and $\mathrm{H}$ area is 5, also typical of SRS soil conditions.[13] The average annual rainfall the past 30 years has been approximately 49 inches [14].

Table 3: Soil Resistivity Data for Area Surrounding the F-area Type IV Tanks.

\begin{tabular}{|c|c|c|}
\hline \multirow{2}{*}{ Depth (ft) } & \multicolumn{2}{|c|}{ Soil Resistivity (ohm-cm) } \\
\cline { 2 - 3 } & Southeast of Tank 19 & Northeast of Tank 17 \\
\hline 2.5 & 71,700 & 24,378 \\
\hline 5 & 68,832 & 30,592 \\
\hline 7.5 & 70,266 & 35,850 \\
\hline 10 & 51,624 & 38,240 \\
\hline 15 & 45,888 & 45,888 \\
\hline Average & 61,662 & 34,990 \\
\hline
\end{tabular}


The understanding of the soils are the SRS were utilized to determine appropriate soils from which corrosion data can be used for life-estimation calculations.

\subsection{Corrosion of Stainless Steel}

An understanding of the soil characteristics is key in determining the corrosion response of the transfer line steel in soil. The database of stainless steel corrosion compiled by the National Bureau of Standards was used to determine the general corrosion rate to be used for the calculation.[15] A survey of the data revealed that the Hagerstown Loam at the Loch Raven (Maryland) 'Site B' is the most appropriate for comparison to the SRS soils. However, an additional site, the Lakewood Sand at the Wildwood (New Jersey) "Site D", was chosen for representative and bounding pitting corrosion data relevant to the SRS soils. The chosen sites, shown in Table 4, exhibit a low total dissolved solids content, resistivity, and good drainage similar to SRS soils.

Table 4: Properties of Relevant Soil Site in Stainless Steel Corrosion Study

\begin{tabular}{|c|c|c|}
\hline Soil Property & Hagerstown Loam Site B, MD & \multicolumn{1}{|c|}{ Lakewood Sand, Site D, NJ } \\
\hline Description & $\begin{array}{l}\text { Well-drained soil representative of } \\
\text { most well-developed soils in } \\
\text { eastern US, brown loam (1ft) } \\
\text { underlain by red-brown clay (5ft) } \\
\text { underlain by rock. }\end{array}$ & $\begin{array}{l}\text { White, loose sand with some black streaks, } \\
\text { supports abundant growth of beach grasses. } \\
\text { Well-drained. }\end{array}$ \\
\hline pH & 5.3 & 5.7 \\
\hline $\begin{array}{c}\text { Resistivity, } \\
\text { ohm-cm }\end{array}$ & $12,600-34,760$ & $13,800-57,500$ \\
\hline TDS & Very low & Very low \\
\hline Drainage & Good & Good \\
\hline \hline
\end{tabular}

The corrosion studies observed the general corrosion and pitting of stainless steels in soil in the annealed, sensitized and welded coupons.[15] In general, the corrosion on the annealed materials was nil or superficial for the annealed coupons buried for up to 8 years at the sites of interest. Corrosion on the sensitized coupons was nil or negligible for those exposed to Site 'B', while small pits appeared on those exposed to Site 'D'. Corrosion of the welded coupons was nil or negligible when exposed to either of the site. The general corrosion rate data for the sensitized material exposed to Site 'B' was used for the life estimation calculations since only these coupons exhibited observable general corrosion. The pitting rate data from the sensitized coupons exposed to Site ' $\mathrm{D}$ ' was used for the pitting calculations, since only these exhibited pitting.

\subsubsection{General Corrosion of Stainless Steel}

Figure 4 shows the general corrosion rate as a function of time for sensitized Type 304-SS exposed to Site ' $\mathrm{B}$ '. The corrosion rate was calculated by converting the weight loss data using the geometrical information of the coupons. It was assumed that the general corrosion was uniform over the entire surface of the coupons. The corrosion rate is seen to decrease with time as expected. A power law was fit to the curve to determine an appropriate corrosion rate for application to life estimation calculations. The data indicates that the corrosion rates fall to extremely low levels. A general corrosion rate of 0.04 mils/year $(1 \mu \mathrm{m} /$ year) will be used for the life estimation as a bounding case, although the data indicate a much lower corrosion rate. 


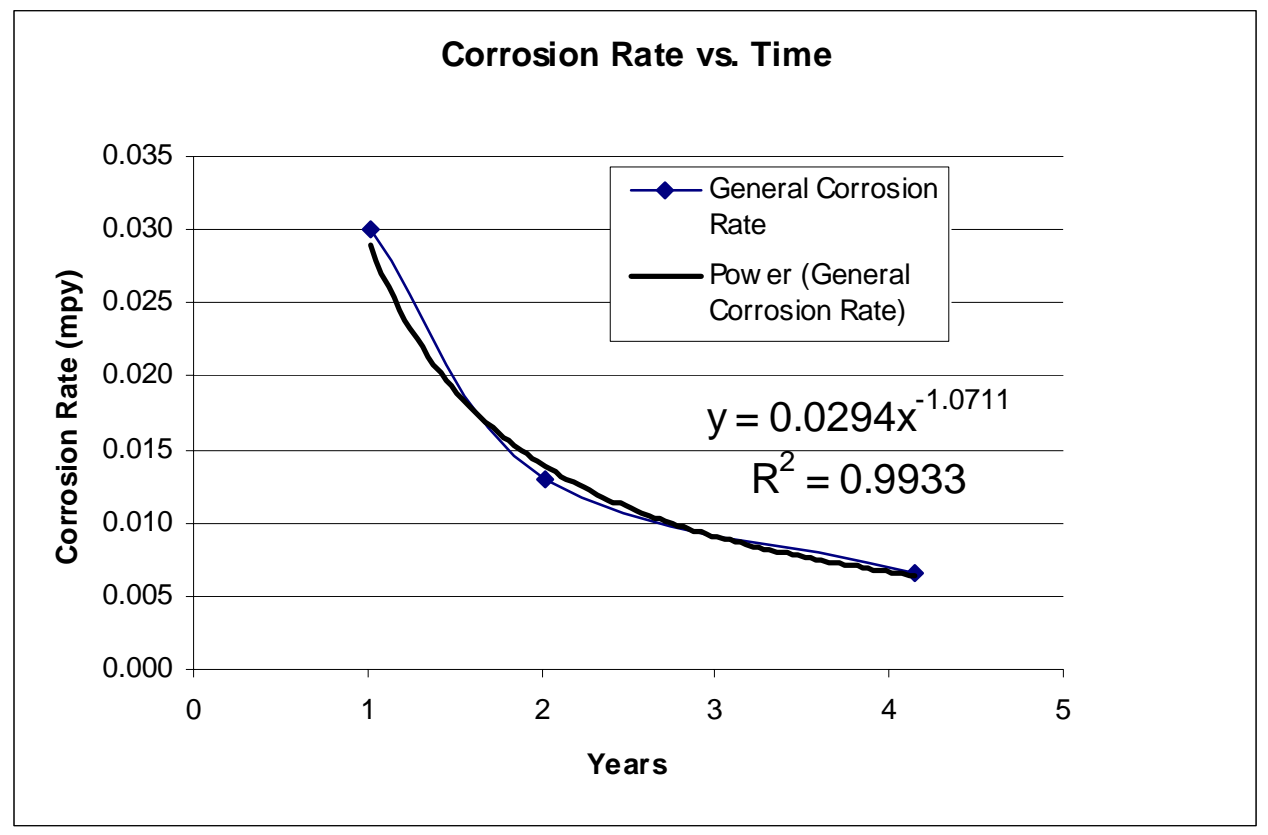

Figure 4: Corrosion Rate vs. Time for Sensitized Type 304-SS Exposed to Site 'B'.

\subsubsection{Pitting Corrosion of Stainless Steel}

Figure 5 shows the pitting corrosion rate, measured as the maximum penetration rate (i.e. thru wall) as a function of time for sensitized Type 304-SS exposed to Site 'D'.

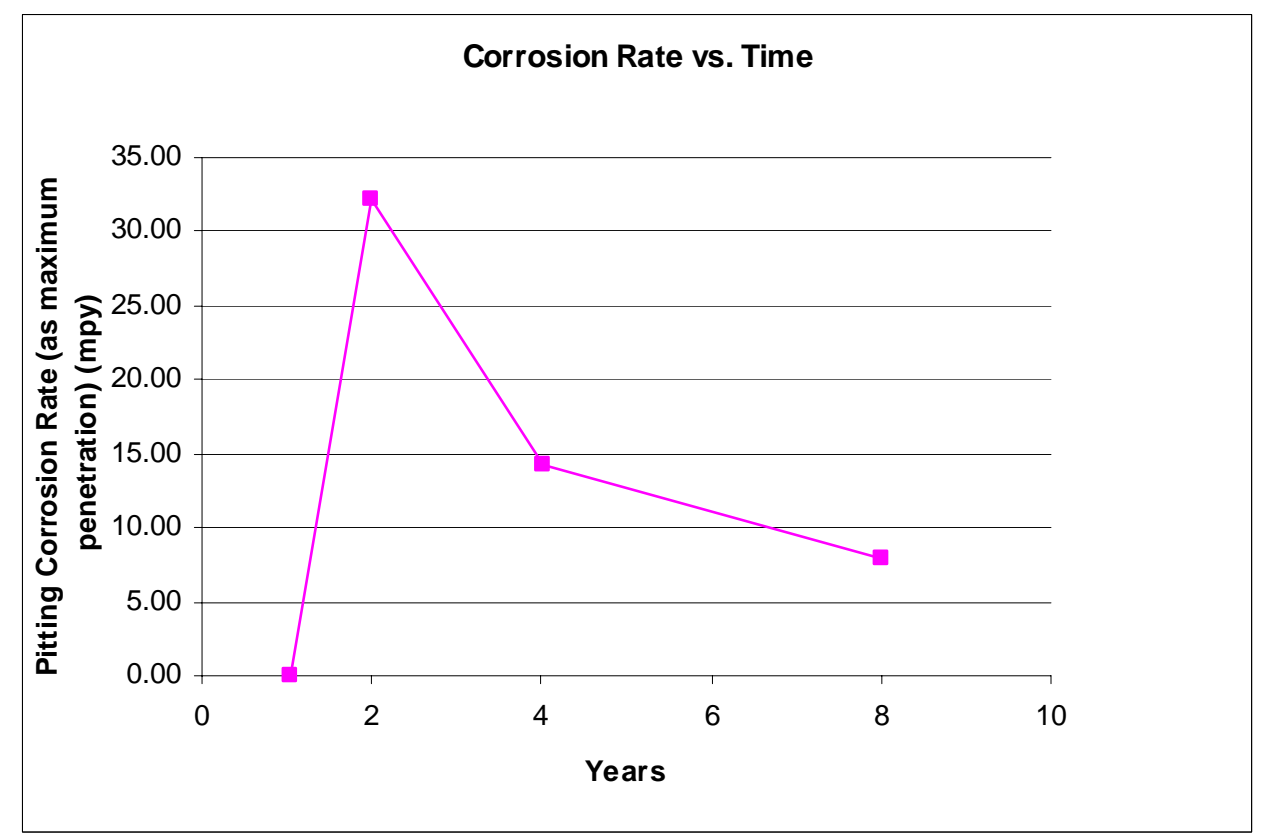

Figure 5: Corrosion Rate as Maximum Penetration Rate vs. Time of Type 304-SS Exposed to Site 'D'.

A power law fit to the data which showed observable corrosion yielded:

$$
\text { CorrosionRate }=61.597 t^{-1.0002}
$$


Where: Corrosion (pitting) rate: mils/year

$\mathrm{t}=$ time (years)

Analyses of the data revealed a pitting rate of 8 mils/year for the coupon with the longest exposure time. The data was extrapolated to one order of magnitude utilizing the power-law fit which yielded a corrosion rate of 0.76 mil/year. As a bounding estimate, a pitting corrosion rate of 1 mil/year will be used for the pitting corrosion calculations

\subsection{Corrosion of Carbon Steel}

Another database of metallic corrosion compiled by the National Bureau of Standards was used to determine the general corrosion rate to be used for the life estimation calculations performed on carbon steel.[4] A survey of the data revealed that soil conditions at the Atlanta test site, shown in Table 5, are comparable and yet conservative with respect to resistivity and $\mathrm{pH}$ in comparison to SRS soils.

Table 5: Soil Conditions Used for Analysis

\begin{tabular}{|l|l|}
\hline Location & Atlanta, GA \\
\hline Type of Soil & Cecil clay loam \\
\hline Resistivity of Soil & 17,790 ohm-cm \\
\hline pH of Soil & 4.8 \\
\hline Mean Temperature & $61.2^{\circ} \mathrm{F}$ \\
\hline Annual Precipitation & $48.3-$ in. \\
\hline Moisture Equivalent & $33.7 \%$ \\
\hline
\end{tabular}

\subsubsection{General Corrosion of Carbon Steel}

The weight-loss and maximum penetration data presented in Reference 4 for open-hearth steel plate was used to calculate the corrosion rate and maximum penetration rate, i.e. localized corrosion rate. The results are shown in Table 6.

Table 6: Weight Loss of Carbon Steel in Cecil Clay Loam Soil

$\begin{array}{cccc}\text { Years } & \text { Weight Loss }(\mathbf{k g} / \mathrm{m} 2) & \text { Corrosion Rate }(\mu \mathrm{m} / \mathrm{yr}) & \text { Max Penetration }(\mu \mathrm{m} / \mathrm{yr}) \\ 2 & 0.54\left(1.8 \mathrm{oz} / \mathrm{ft}^{2}\right) & 34.78(1.37 \mathrm{mpy}) & 508(20 \mathrm{mpy}) \\ 5.5 & 0.96\left(3.2 \mathrm{oz} / \mathrm{ft}^{2}\right) & 22.48(0.89 \mathrm{mpy}) & 351(13.82 \mathrm{mpy}) \\ 7.6 & 1.18\left(3.9 \mathrm{oz} / \mathrm{ft}^{2}\right) & 19.83(0.78 \mathrm{mpy}) & 191(7.5 \mathrm{mpy}) \\ 9.5 & 1.02\left(3.4 \mathrm{oz} / \mathrm{ft}^{2}\right) & 13.83(0.54 \mathrm{mpy}) & 193(7.58 \mathrm{mpy}) \\ 14.3 & 1.21\left(4 \mathrm{oz} / \mathrm{ft}^{2}\right) & 10.81(0.43 \mathrm{mpy}) & 139(5.45 \mathrm{mpy})\end{array}$

The general corrosion rate and the maximum penetration are shown in Figure 6 as a function of time. The data shows that the corrosion rate decreases with time typically in a power-law relationship. 


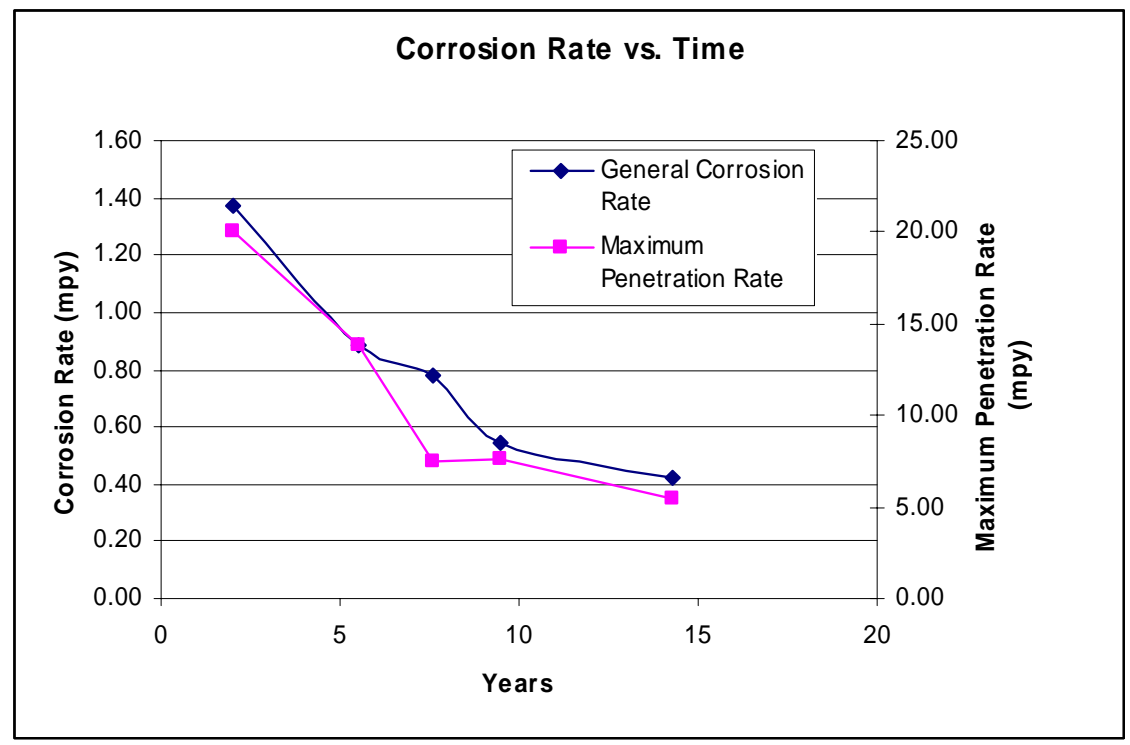

Figure 6: Corrosion Rate and Maximum Penetration Rate as a Function of Time.

The general corrosion rate of 0.4 mils/year can be used as a conservative estimate for corrosion of the carbon steel transfer lines.

\subsubsection{Pitting Corrosion in Carbon Steels}

The maximum pit depth can be estimated by:

$$
h=k t^{n}\left(\frac{A}{372}\right)^{a}
$$

$\begin{array}{rll}\text { where: } \mathrm{k} & = & \text { empirical pitting parameter }\left(\mathrm{m} / \mathrm{yr}^{\mathrm{n}}\right) \\ \mathrm{t} & = & \text { corrosion time }(\mathrm{yr}) \\ \mathrm{n} & = & \text { empirical pitting exponent } \\ \mathrm{A} & = & \text { representative surface area }\left(\mathrm{cm}^{2}\right) \\ \mathrm{a} & = & \text { experimentally derived empirical coefficient }\end{array}$

The (A/372) ${ }^{\mathrm{a}}$ term is a correction term to account for the statistical nature of pitting that leads to a higher probability of finding a deeper pit the larger the area studied. Regression analysis of pitting data yielded values of 34.49 and 0.3205 respectively for ' $k$ ' and ' $n$ '.[8] Literature values report a mean of 0.15 for exponent 'a'.[16] Using these values, the final form of the equation is:

$$
h(\text { mils })=56.56 t^{0.3205}
$$

$\begin{array}{llll}\text { where: } & \mathrm{h} & = & \text { pit depth (mils) } \\ \mathrm{t} & = & \text { corrosion time (year) }\end{array}$

This final form will be used for transfer line life estimation for the carbon steel liners.

\section{TRANSFER LINE LIFE ESTIMATION RESULTS}

The life of the transfer line was estimated for general corrosion as well as pitting corrosion for exposure to soils. 


\subsection{Life Estimation of Stainless Steel Transfer Lines}

The life of the stainless steel transfer lines was estimated for general corrosion based upon the bounding rate of 0.04 mpy. The general corrosion is assumed to proceed homogenously throughout the surface of the transfer line, until complete consumption of the metal due to general corrosion. The lifetimes of each of the types of stainless steel transfer lines due only to general corrosion are shown in Figure 7. It is seen that even the minimum thickness stainless steel lines are expected to provide confinement for 2900 years for conservative corrosion rate estimates.

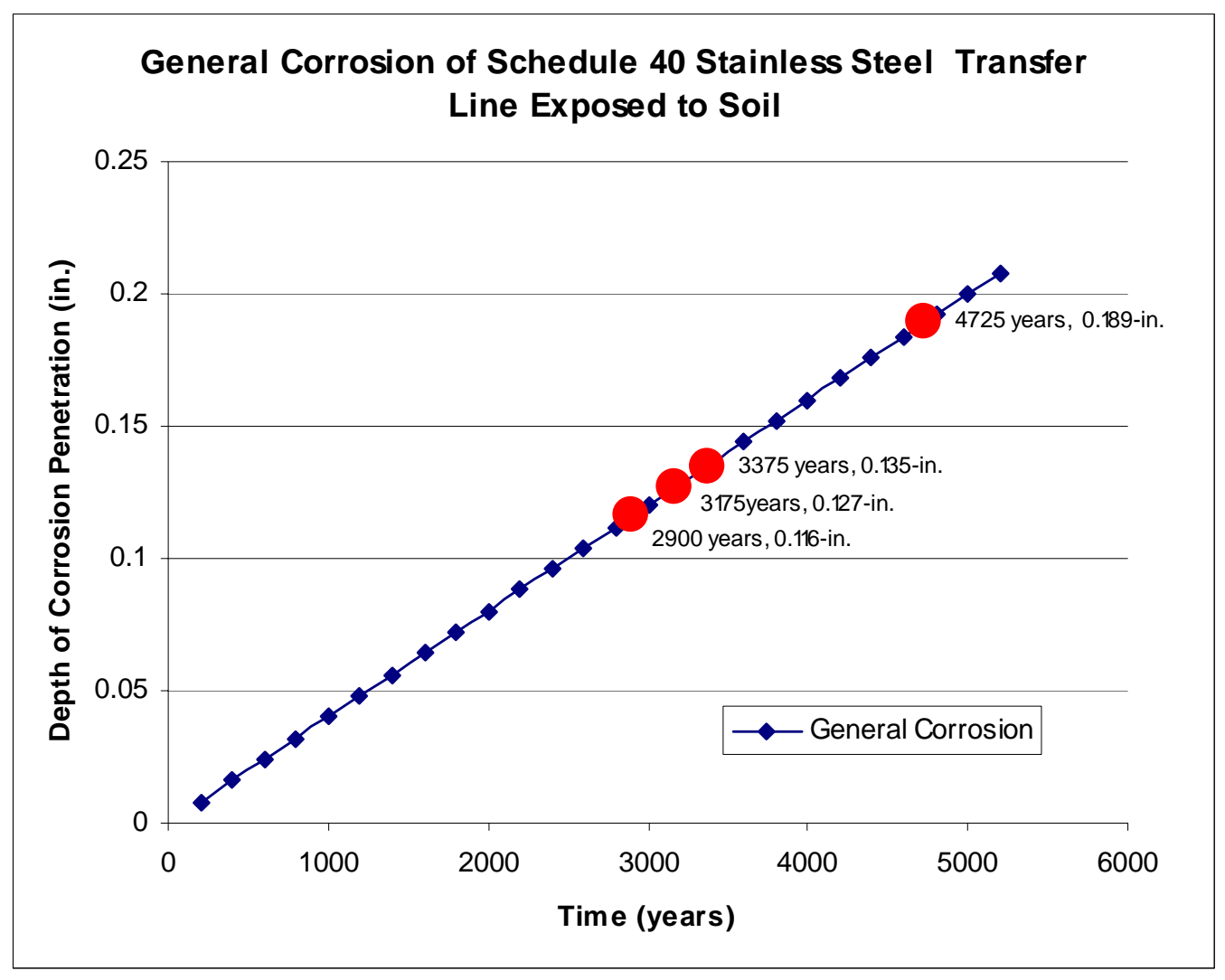

Figure 7: General Corrosion of Schedule 40 Stainless Steel Transfer Lines exposed to Soil

The breach of the stainless steel transfer line due to pitting was also calculated. The maximum pitting rate of 1 mil/year was used as a linear rate for the initial pitting. The pitting model assumes formation of a hemispherical pit and estimates the area breached based upon the maximum pit depth, the corrosion allowance, and the number of penetrating pits per a given area:

$$
A_{b}=N_{p} \pi\left(h^{2}-d^{2}\right)
$$

where: $\mathrm{A}_{\mathrm{b}} \quad=\quad$ Area breached $\left(\mathrm{m}^{2}\right)$

$\mathrm{N}_{\mathrm{p}}=$ penetrating pits per container $\left(\mathrm{pits} / \mathrm{m}^{3}\right)$ - assumed to be 500 per $\mathrm{m}^{2}[5]$

$\mathrm{h}=$ maximum pit depth $(\mathrm{m})$

$\mathrm{d}=$ corrosion allowance

Obviously, the first pit is estimated to penetrate the stainless steel transfer lines utilizing the $1 \mathrm{mil} / \mathrm{year}$ pitting rate is as follows: 
Transfer Line Thickness (in.) Estimated First Pit Penetration (yrs)

$\begin{array}{ll}0.116 & 116 \\ 0.127 & 127 \\ 0.135 & 135 \\ 0.189 & 189\end{array}$

The percentage breached of stainless steel transfer lines is shown in Figure 8 . The time to $25 \%$ breach is estimated as follows:

$\begin{array}{cc}\text { Transfer Line Thickness (in.) } & \text { 25\% breach (yrs) } \\ 0.116 & 510 \\ 0.127 & 513 \\ 0.135 & 515 \\ 0.189 & 532\end{array}$

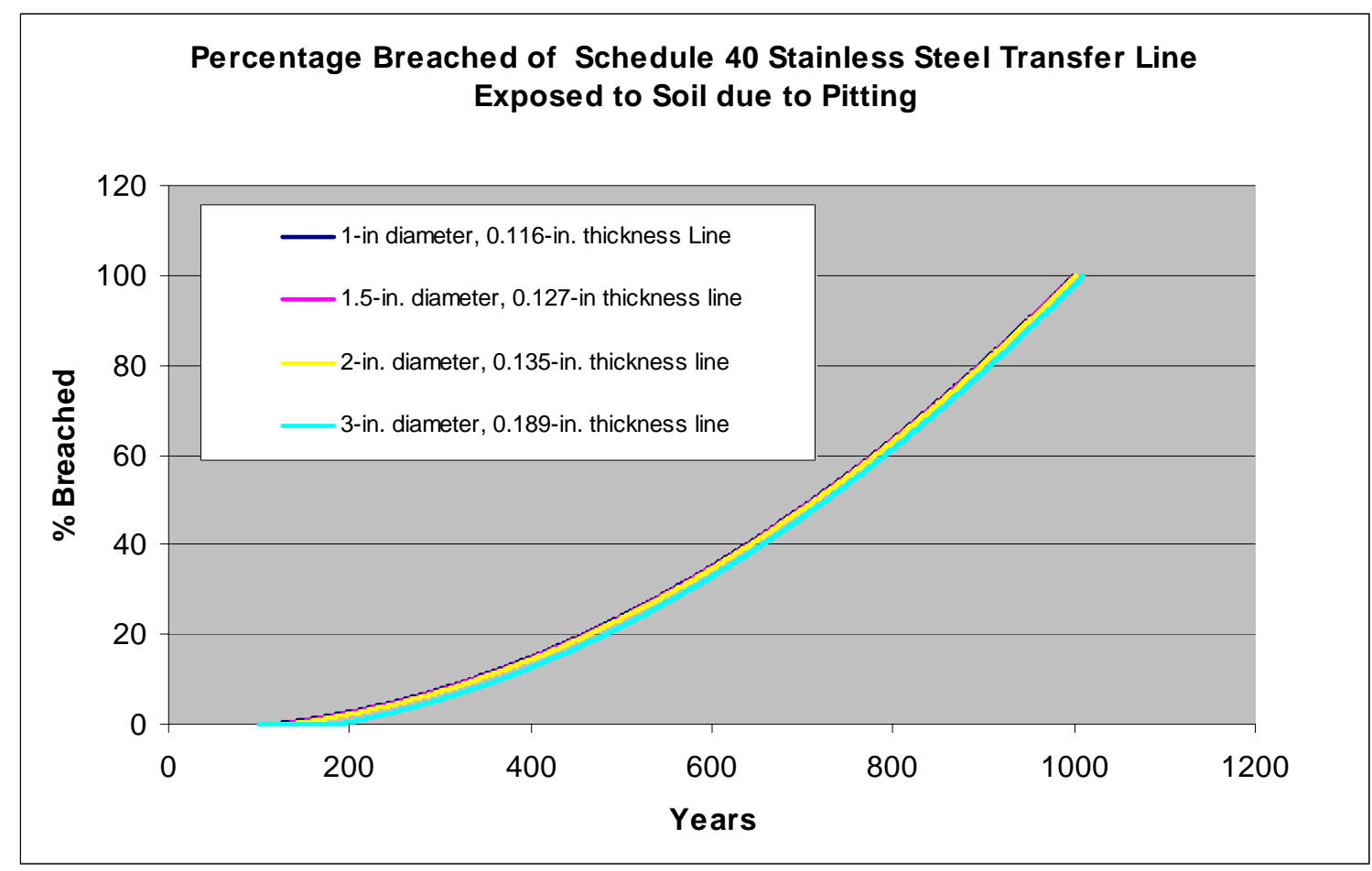

Figure 8: Percentage of Area Breached of Stainless Steel Transfer Line due to Pitting in Soil

It is clear that the pitting controls the life estimation of the stainless steel transfer lines.

\subsection{Life Estimation of Carbon Steel Transfer Lines}

The only carbon steel transfer lines are the Type IIA transfer lines which are schedule 40 piping of 3-in diameter with a minimum thickness of 0.189-in. Once again, The pitting model assumes formation of a hemispherical pit and estimates the area breached based upon the maximum pit depth, the corrosion allowance, and the number of penetrating pits per a given area: 


$$
A_{b}=N_{p} \pi\left(h^{2}-d^{2}\right)
$$

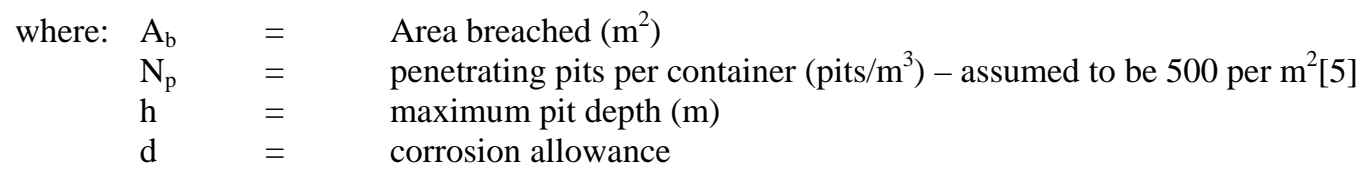

The corrosion of the carbon steel transfer line when exposed to soil is shown in Figure 9. The maximum pit depth and depth of general corrosion are shown as a function of time. The first pit is estimated to penetrate thru-wall at 43 years, while the general corrosion is estimated to consume the transfer line steel at 440 years.

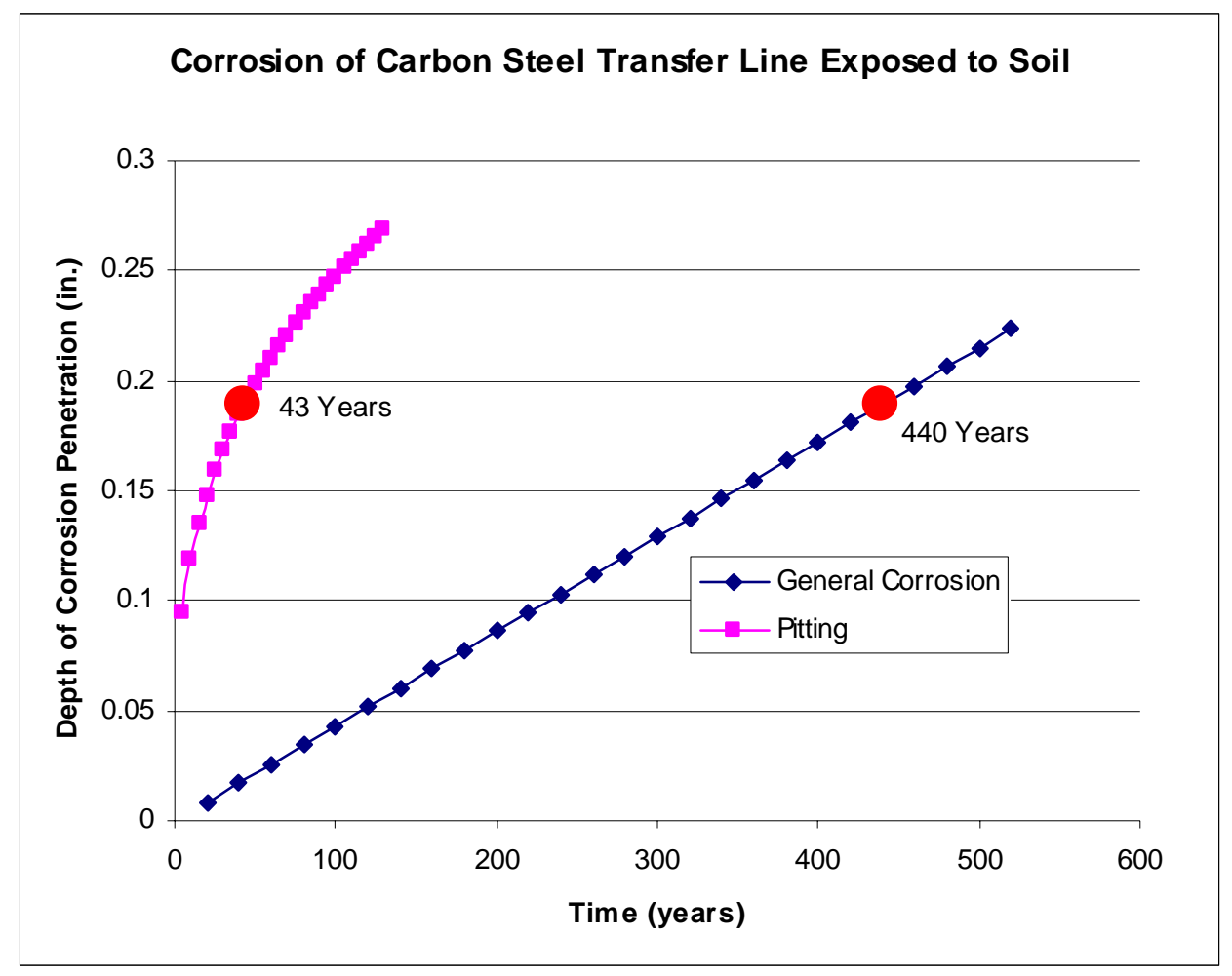

Figure 9: Corrosion of Carbon Steel Transfer Line Exposed to Soil

The corresponding percentage of area breached will be presented in the following section.

\section{RECOMMENDATIONS \& CONCLUSIONS}

It is clear that pitting corrosion is the controlling mechanism for the degradation of the transfer lines and their consequent ability to maintain confinement of contaminants. It is assumed that $75 \%$ of the transfer line is needed intact to provide this confinement function, i.e. once $25 \%$ of the line wall is breached, the lines are considered incapable of confining contaminants. It is recommended that the percentage breached curves be utilized for each transfer line as shown in Figure 10 for the various stainless steel transfer lines. 


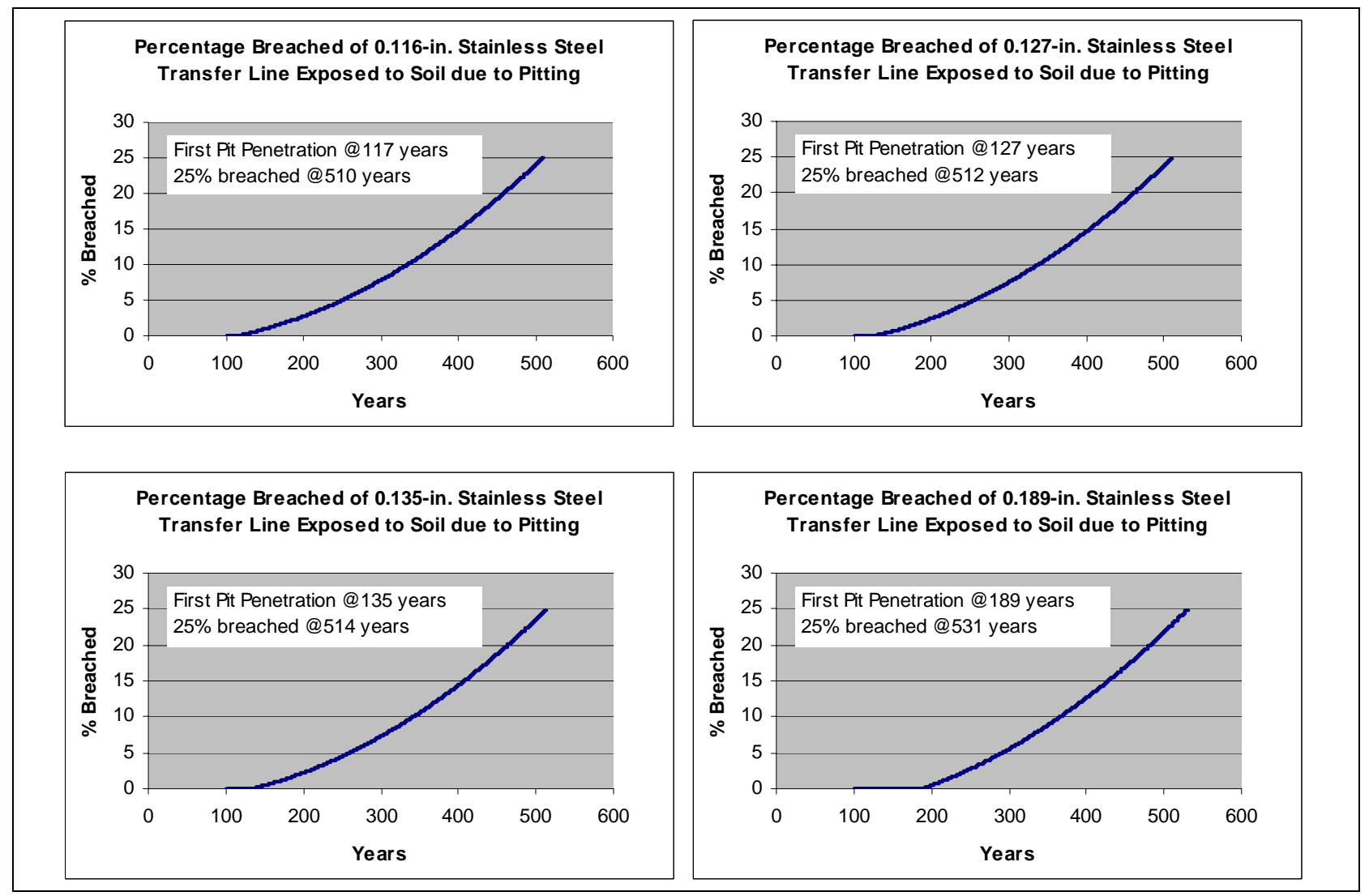

Figure 10: Recommended Life Estimation for Stainless Steel Transfer Lines for Contaminant Modeling.

A similar curve was developed for the carbon steel transfer lines, as shown in Figure 11. The first pit is estimated to penetrate at 43 years, and $25 \%$ of the line wall is breached at an estimated 98 years.

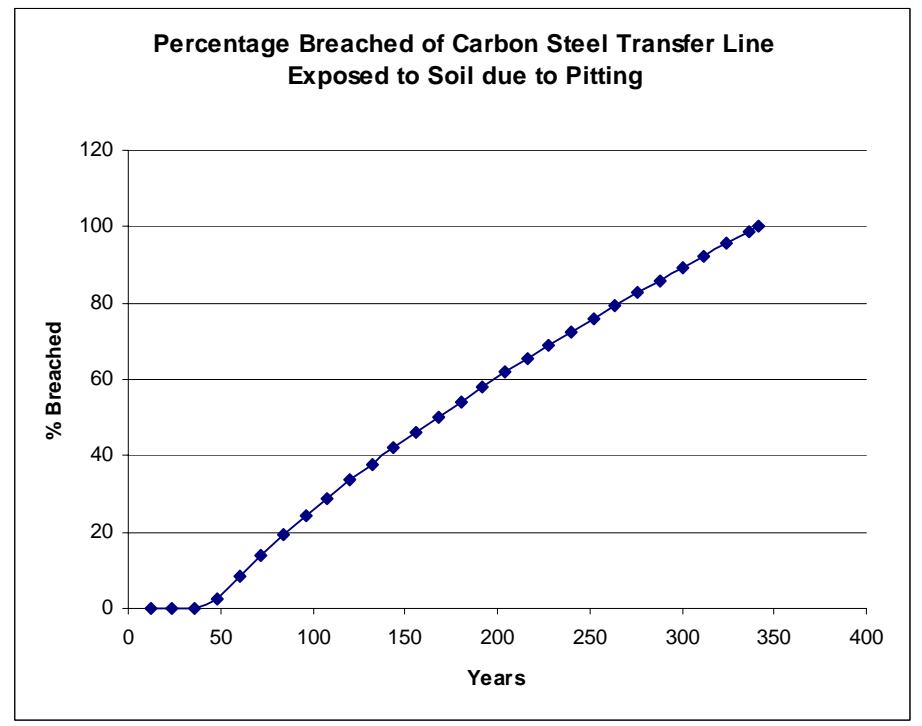

Figure 11: Percentage of Carbon Steel Transfer Line due to Pitting 


\section{REFERENCES}

[1] Standard Specifications for Seamless, Welded, and Heavily Cold Worked Austenitic Stainless Steel Pipes, ASTM A312/312M-05A, ASTM International, West Conshohocken PA 2005.

[2] B. Huet, V.L. Hostis, F. Miserque, H. Idrissi, "Electrochemical Behavior of Mild Steel in Concrete: Influence of pH and Carbonate Content of Concrete Pore Solution,” Electrochimica Acta, 51 (2005), pp. 172-180.

[3] B.J. Wiersma, “F-Area Type IV Tank Liner Life Estimation,” WSRC-TR-2005-00369, Westinghouse Savannah River Company, October 2005.

[4] M. Romanoff, Underground Corrosion, National Bureau of Standards Circular 579, April 1957.

[5] T.M. Sullivan, “Assessment of Release Rates for Radionuclides in Activated Concrete,” BNL-71537-2003, Brookhaven National Laboratory, August 2003.

[6] Corrosion Basics: An Introduction, Published by NACE International, Houston Texas, 1984.

[7] Soil Survey of Savannah River Plant Area, Parts of Aiken, Barnwell, and Allendale Counties, South Carolina, National Cooperative Soil Survey, 1987.

[8] K.H. Subramanian, “Corrosion Analysis for Tritium Extraction Facility Disposal in Pre-Disposal Configuration,” WSRC-TR-2005-00220, Westinghouse Savannah River Company, Aiken SC, May 2005.

[9] “Corrosion Survey Report,” 200-F Separations Area at the Savannah River Plant, EBASCO, July 1982.

[10] R.A. Corbett and C.F. Jenkins, “ Soil Characteristics as Criteria for Cathodic Protection of a Nuclear Fuel Production Facility,” Effects on Soil Characteristics on Corrosion, ASTM STP 1013, ASTM International, West Conshohocken, Pennsylvania, 1989.

[11] “Corrosion Investigation And Feasibility Study of Cathodic Protection For Underground Waste Storage Tanks and Process Lines in H-Area At the Savannah River Plant,” Harco Corporation, July 1982.

[12] D'Appolonia, “Report: DWPF - Stage I Investigation Plan of Excavation and Backfill,” Submitted to E.I. DuPont De Nemours and Company, Aiken, South Carolina, September 1981.

[13] B. J. Wiersma, “Estimation of High Level Waste (HLW) Tank Remaining Service Life,” WSRC-TR-200500196, Westinghouse Savannah River Company, Aiken, South Carolina, May 2005.

[14] SRS Atmospheric Technologies Database.

[15] W.F Gerhold, E. Escalante, B.T. Sanderson, “The Corrosion Behavior of Selected Stainless Steels in Soil Environments,” NBSIR 81-2228, National Bureau of Standards, February 1981.

[16] K.H. Logan, “Engineering Significance of National Bureau of Standards Soil Corrosion Data,” Journal of Research of the National Bureau of Standards, Vol. 22, 1989. 